\title{
YAMPIL BARROW COMPLEX: PRYDNISTRYANSKE 1 AND KLEMBIVKA 1. PEDOLOGICAL-ENVIRONMENTAL ASPECTS OF LOCATION
}

\begin{abstract}
The paper presents results of pedological studies of Klembivka site 1 and Prydnistryanske site 1 barrow IV and the reference soil profile Prydnistryanske site 1 in the context of pedostratigraphy, basic soil properties, construction material origin and palaeoenvironmental implications.
\end{abstract}

ABSTRACT

Key words: Chernozems, forest-steppe zone, calcic horizon, kurgans (barrows), pedoarchaeology

Soil conditions have always been a major environmental factor in locating human activity. Apart from their fundamental role in natural ecosystems, soils have provided a base for the planned cultivation of chosen crops and determined if it was successful and what direction it took. On the other hand, soil morphological structure and properties reflect the special character of the soil-forming environment, that is, the natural geographical environment and the human activity interfering in the soil [Karpachevski 1983; Bednarek 2007]. Apart from being used for crop cultivation, soils were a basic, universally available and easily procured building material of anthropogenic structures. Such earthen structures include barrows. The study of the material they are built of and soil properties around them may, in

\footnotetext{
Department of Soil Science and Landscape Management, Faculty of Earth Sciences, Nicolaus Copernicus University, ul. Lwowska 1,87-100 Toruń, Poland; mijank@umk.pl, michal.dabrowski@ op.pl, justynaj1804@wp.pl, adamich@o2.pl
} 


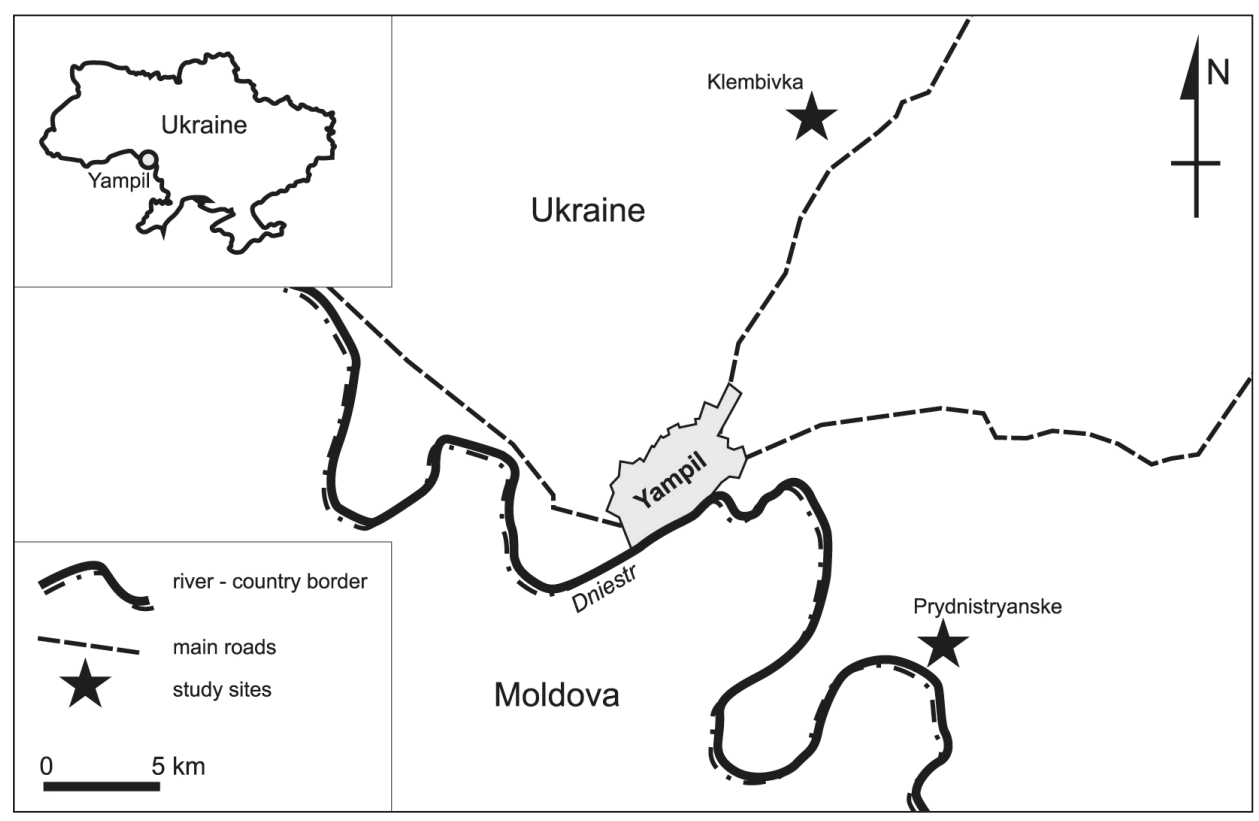

Fig. 1. Location of the study sites

favourable conditions, be helpful in reconstructing the environmental conditions that prevailed when they were being built and also later environment changes. It may even shed some light on the preferences and customs of their builders.

The study of soils within the Yampil Barrow Complex (YBC) was undertaken on the invitation from Prof. Aleksander Kośko. The first barrow mound to be studied was Pidlisivka 1 explored in 2010 [Bednarek, Jankowski 2014]. This article presents the results of the next stage of investigations centred on the structure of other two barrows, designated as Prydnistryanske 1-IV [Klochko et al. 2015b] and Klembivka 1 [Klochko et al. 2015a]. Characteristics of barrow building materials in comparison with natural soil and also an attempt of their pedological-environmental interpretation are the aim of this work.

The study involved the analysis of a set of soil samples and vertical cores collected in the course of archaeological excavations. The samples and cores represented barrow mound strata and their contact with the underlying remains of original soils. The samples were analyzed for basic physical and chemical properties, determining the genetic characteristics and origin of barrow building materials, using standard methods employed in soil science: hydrometric (BouyoucosCasagrande) and sieve for particle size distribution, Tiurin wet-burning for organic carbon (OC) content, Kjeldahl for total nitrogen content (Nt), potentiometric for $\mathrm{pH}$ measured in ultrapure $\mathrm{H}_{2} \mathrm{O}$ and $1 \mathrm{~mol} / \mathrm{dm}^{3} \mathrm{KCl}$, Scheibler for $\mathrm{CaCO}_{3}$ content and Bleck as modified by Gebhardt for phosphorus content (Pt). To interpret cor- 
rectly the barrow-building materials, the investigations were extended to cover the analysis of the reference soil profile Prydnistryanske 1, located at the site of the same name in the immediate vicinity of the complex of four barrows.

\section{ENVIRONMENTAL-PEDOLOGICAL CONDITIONS AROUND YAMPIL}

The YBC is situated in the northern left-bank part of the Dniester drainage basin (Fig. 1). The barrows rise from a loess plateau, gently descending north-south, in the direction of the river ravine edge. Around Klembivka, the plateau surface stretches at about 250-270 m a.s.1., while around Prydnistryanske 1 it rises to about 180-200 m. a.s.l. A special relief feature is the domination of vast undulating or flat surfaces cut by many ravines and gorges, belonging to the Dniester fluvial system, having impressive depths exceeding $100 \mathrm{~m}$ or locally even $160 \mathrm{~m}$. According to a topographic map, the water level of the Dniester, at the shortest distance from Prydnistryanske 1, extends at about $41 \mathrm{~m}$ a.s.l.

The plateau surface is built of Pleistocene loess formations, being the parent rock of contemporary soils. The loess cover lies over older rocks the outcrops of which can be seen on Dniester valley slopes and in quarries worked on the Ukrainian and Moldavian sides of the river alike. The Pleistocene formations are underlain by the plates of Tertiary, Mesozoic and Palaeozoic sedimentary rocks. Underneath, the granites of the Precambrian Ukrainian Shield are exposed in several locations [Siemiradzki 1922; Boguckyj et al. 2007]. The bottoms of ravines and side valleys are filled with colluvial and alluvial materials, coming chiefly from loess re-deposition already in the Holocene. The Dniester valley bottom is built of Holocene alluvial deposits.

In bioclimatic terms, the south-eastern part of western Ukraine is considered a part of a forest-steppe zone [Zastawnyj, Kusiński 2003]. It is characterized by a mosaic of potential steppe vegetation and deciduous forests. On Ukraine's map of vegetation, the area in question has been marked for the most part as 'arable land in place of oak forests'. However, the immediate vicinity of Yampil is marked on maps as a wedge of meadow steppe stretching along the Dniester and interspersed with small enclaves of oak and oak-hornbeam forests. This fact alone attests to special geo-ecological conditions, including soil-forming ones, present in the area under investigation when compared to the surrounding area. Boguckyj et al. [2007] use the designation 'Ukrainian subtropics' with regard to the Dniester valley, which reflects the differences between this area and the rest of this part of the country in terms of landscape and climate. 


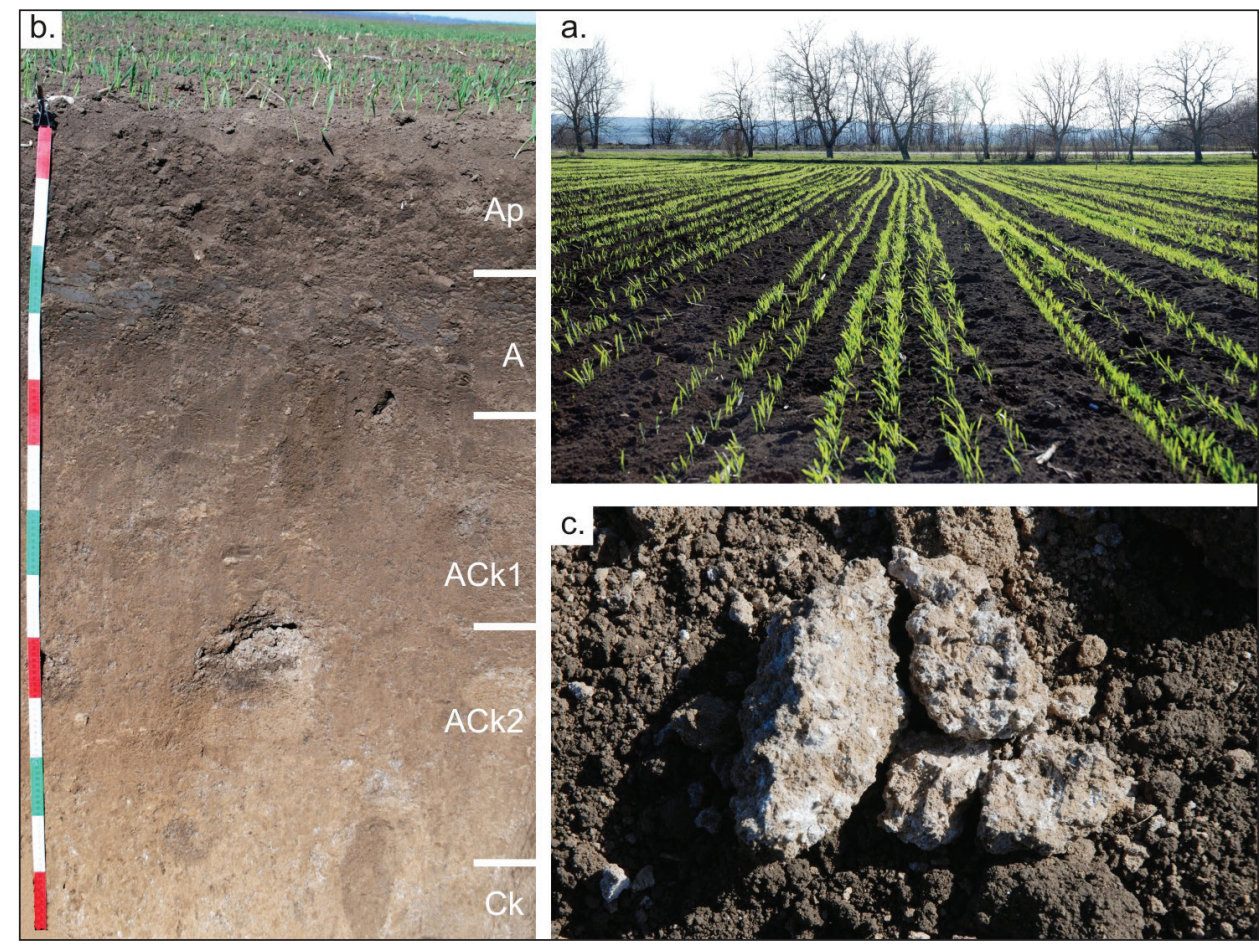

Fig. 2. Morphology of the reference soil profile Prydnistryanske site 1: a. soil surface, b. soil profile (horizons marked with standard symbols used in soil science), c. $\mathrm{CaCO}_{3}$ concentration in the Ck calcic horizon

Typical soils in the forest-steppe zone include above all degraded and 'podzolized' chernozems and (dark-) grey forest soils [Bednarek, Prusinkiewicz 1980; Baliuk et al. 2017], occurring also as a mosaic. A comparison of the bioclimatic conditions with peculiar geomorphological features reveals, however, a certain special characteristic of the mosaic landscape around Yampil. The wide distribution of potential steppe or meadow-steppe vegetation may be associated with the elevated, sun- and wind-exposed, relatively dry hilltops of the loess plateau. In its soil cover, chernozems with steppe rather than forest-steppe characteristics may be expected to dominate. Deciduous forests, in turn, should be mainly connected with more humid conditions prevailing in valleys and on their slopes, potentially covered by grey forest soils as well as colluvial and alluvial soils. 


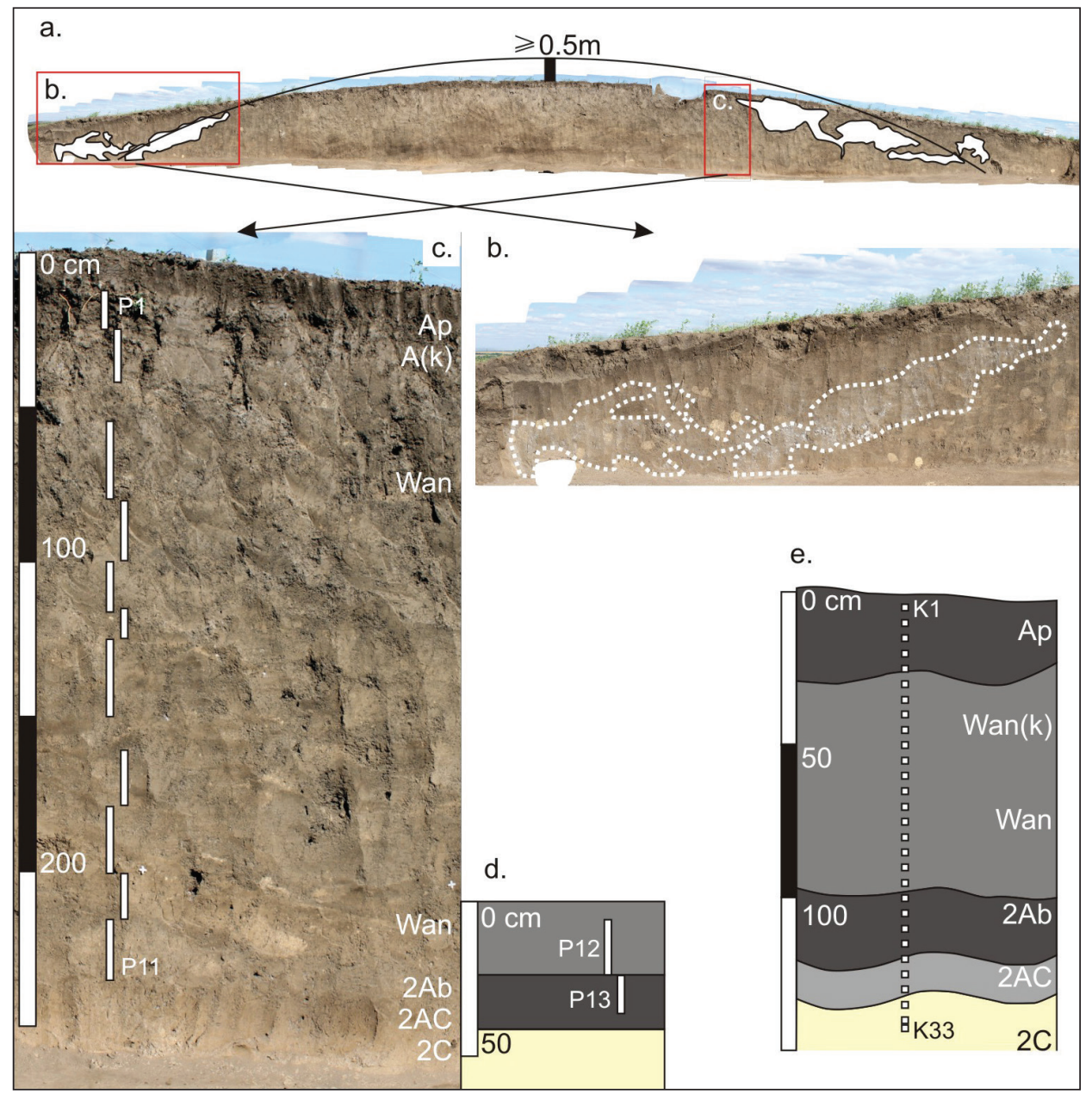

Fig. 3. Morphology of barrows: Prydnistryanske, Yampil Region, site 1, barrow IV: a. crosssection $\mathrm{N}-\mathrm{SO}$, with secondary calcic horizon and probable former barrow height marked, b. closer view of secondary calcic horizon, c. scheme of core 1 sampling (section N-SO), d. scheme of core 2 sampling (section S-NO); and Klembivka 1: e. scheme of barrow sampling (Photo: D. Żurkiewicz)

\section{SOIL MORPHOLOGY IN THE REFERENCE PROFILE} AND BARROWS MOUNDS

The reference soil profile is located at Prydnistryanske 1 site, about $75 \mathrm{~m}$ south of barrow IV and west of barrow II [Klochko et al. 2015b] on the flat, slightly tilted towards the south-west surface of the loess plateau. The area is used to grow crops, 

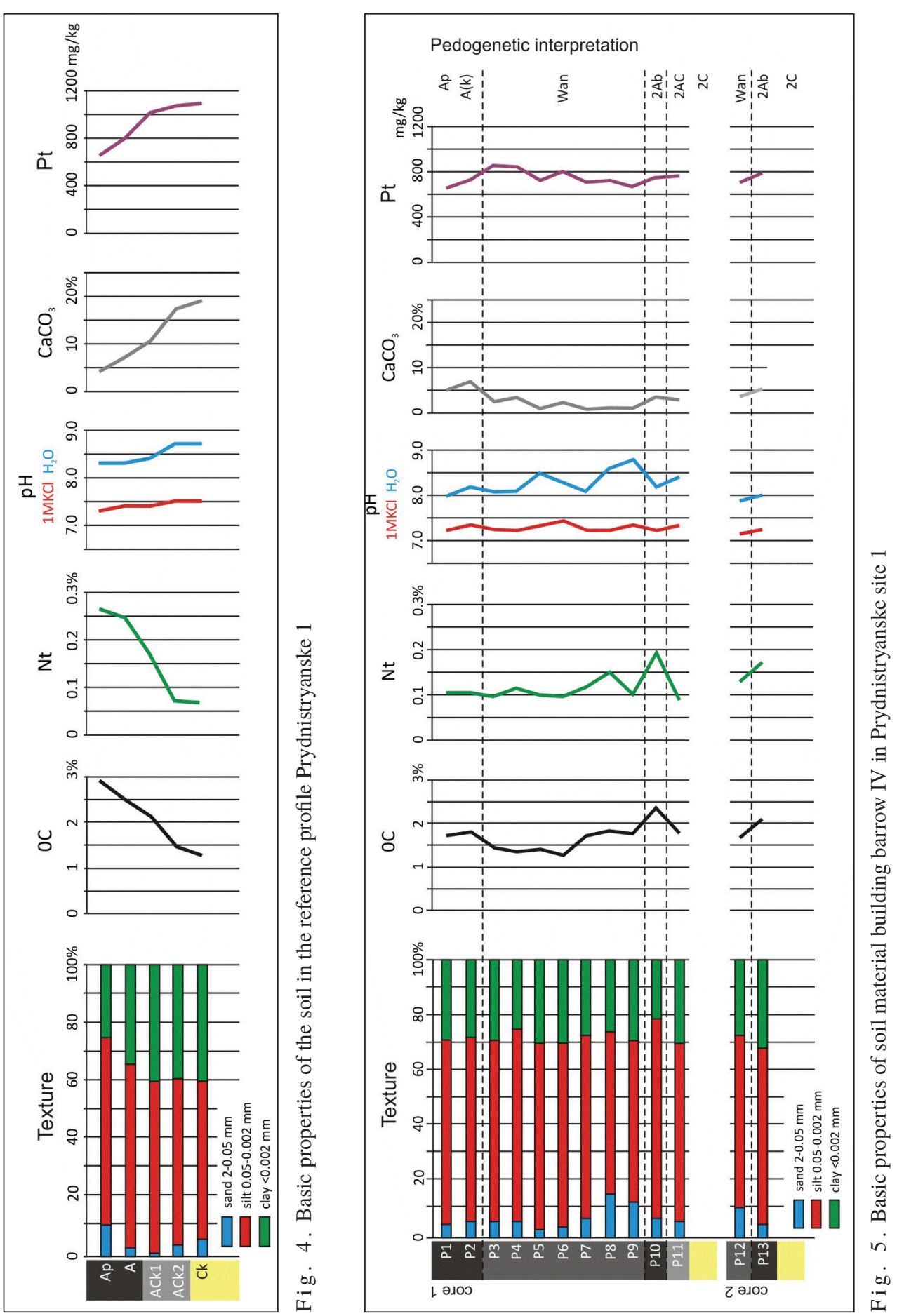
where during field work in early April 2016 sprouting wheat could be seen in the field (Fig. 2a).

The reference profile Prydnistryanske 1 exposes soil the morphological structure of which is characteristic of typical chernozem (Fig. 2b). In its top part, up to a depth of about $45 \mathrm{~cm}$, a humic horizon A is present. It is dark-grey coloured (10YR $2 / 2$ when wet and $2.5 \mathrm{Y} 3 / 3$ when dry) and granular structured. The top layer of this horizon, down to a depth of about $25 \mathrm{~cm}$, is contemporary ploughing horizon Ap. The floor, natural part of humic horizon A, gradually turns into carbonate accumulation horizon $\mathrm{Ck}$. White $\mathrm{CaCO}_{3}$ precipitations, distinct against a dark-yellow colour typical of loess, can be seen already in transitional horizon ACk, from a depth of $45 \mathrm{~cm}$ (Fig. 2c). The entire solum (sequence of genetic horizons above the parent rock) shows traces of great biological activity such as numerous krotovinas (zooturbations), resulting from soil fauna activity and typical of steppe soils.

The original barrow stratigraphy is barely noticeable due to the considerable homogeneity of building materials and the original soil, and the high concentration of krotovinas (post-deposition zoogenic bioturbations; Fig. 3). The mounds of Prydnistryanske 1-IV and Klembivka 1 barrows are built of soil material whose principal properties resemble those of the chernozem humic horizon A in the reference profile Prydnistryanske 1. All studied samples, collected from the mound layers of both barrows, represent loess material of a dark-grey colour, resulting from a high organic matter content. The top layer of the mounds, $20-25 \mathrm{~cm}$ thick, is additionally homogenized by contemporary ploughing. In turn, under the mounds, the remains of original natural soils, on which the barrows were founded, can be seen in places. In terms of morphology, these soils are analogous to contemporary chernozem but differ from it in the lower thickness of the humic horizon A, being only $15-20 \mathrm{~cm}$ thick. It cannot be ruled out that the top part of the natural soils could have been removed in the course of barrow construction.

3. SOIL PROPERTIES IN THE REFERENCE PROFILE AND BARROW MOUNDS

In the Prydnistryanske 1 profile, chernozem is built of silty-clayey loess in which the silty fraction $(0.05-0.002 \mathrm{~mm})$ clearly dominates, making up 55-65 per cent of the granulometric composition. The share of clayey fraction $(<0.002 \mathrm{~mm})$ is considerable, amounting to $24-40$ per cent (Fig. 4). Interestingly, the contemporary surface ploughing horizon is characterized by a higher content, exceeding 10 per cent, of the sandy fraction $(0.05-2.0 \mathrm{~mm})$. 


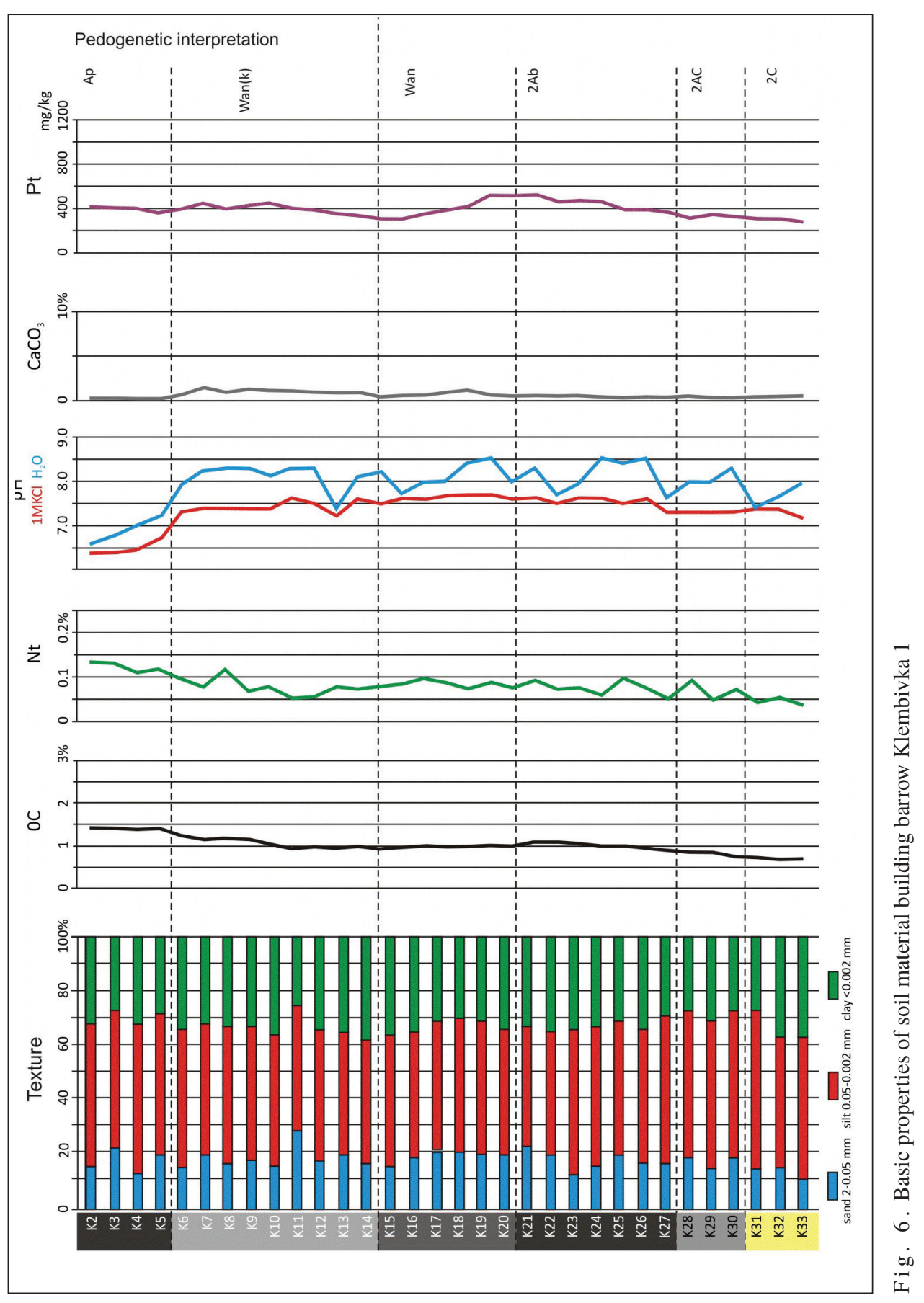


The humic horizon of the soil contains 2.5-3.0 per cent of organic carbon (Fig. 4), that is, approx. 4.0-5.0 per cent of organic matter. Nitrogen content is approx. 0.25 per cent, while the $\mathrm{C} / \mathrm{N}$ ratio is about $10-12$. The reaction of the entire profile is alkaline. The $\mathrm{pH}$ values measured in ultrapure water are 8.3-8.7, while in $1 \mathrm{~mol} / \mathrm{dm}^{3} \mathrm{KCl}-7.3-7.5$. So high a $\mathrm{pH}$ value is connected with the high content of $\mathrm{CaCO}_{3}$ that grows from 4 to 20 per cent when going deeper into the profile. With depth, phosphorus $(\mathrm{Pt})$ content grows as well. In the plough horizon, the content of this element is about $650 \mathrm{mg} \cdot \mathrm{kg}^{-1}$, while in the parent rock, it exceeds $1,000 \mathrm{mg} \cdot \mathrm{kg}^{-1}$. So high a content and its inverse distribution must be considered a geochemical anomaly. According to oral communication from M.V. Potupczyk, phosphorite deposits are found in the vicinity of the site, potentially causing the anomaly.

According to the criteria of the international soil classification, WRB [IUSS Working Group WRB 2015], the above soil properties in the representative profile are diagnostic for the Soil Reference Group Chernozems. The biologically active, deep, humic, alkaline horizon, over $0.5 \mathrm{~m}$ thick, $10 \mathrm{YR} 2 / 2$ black and cloddy, containing over 2.5 per cent (over 1 per cent and 1 per cent more than in $\mathrm{Ck}$ ) of organic carbon fully meets the criteria of the chernic horizon in its deep variety (pachic). Carbonate accumulation horizon $\mathrm{Ck}$ (and ACk2), containing over 15 per cent $(<25 \%$ ) of $\mathrm{CaCO}_{3}$, at a depth of up to $50 \mathrm{~cm}$ below the floor of the chernic horizon, chiefly in the form of secondary precipitations, meets the criteria of a calcic (hypocalcic) horizon. The particle size of silt-clay and the very large number of zoogenic bioturbations (krotovinas) permit the use of the respective qualifiers loamic and vermic.

Consequently, according to the WRB 2015 classification, the analyzed soil has been defined as Vermic Hypocalcic Chernozem (Loamic, Pachic). Such a soil must be considered typical of the environmental conditions prevailing in the transition zone of the subboreal belt [Bednarek, Prusinkiewicz 1980], characterized by a temperate climate with clearly marked continental traits and lush steppe vegetation.

The material of which barrow mound layers are built has a granulometric composition analogous to that of the soil in the reference profile (Fig. 4, 5, 6). It is solely anthropogenically redeposited silty and silty-clayey loess, with the silty fraction dominating. Samples from Klembivka 1 barrow show a slightly higher content of the sandy fraction (15-23\%) than samples from barrow 1-IV and the soil at Prydnistryanske $1(3-16 \%)$. This may be a result of natural sedimentological differentiation of loess sediments.

Both barrows under investigation are characterized by a slightly higher content of the sandy fraction in the floor layers of the mounds, analogously to the top part of the humic horizon of the natural soil in the reference profile Prydnistryanske 1 and in fossil soil remains underneath the barrows. This shows that earth material scooped directly from the surface of the ground was used to build the bottom layers of the barrows.

All studied samples from barrow mound layers contain a considerable amount of organic matter. Carbon content in Klembivka 1 is approx. 1-1.2 per cent, while 
in Prydnistryanske 1-IV, it is from 1.2 to 2.3 per cent. It is worth noting that slightly higher values are found in the bottom layers of the mounds, attesting that the building material came from the surface layers of soils. Nitrogen content is about 10-18 times smaller than organic carbon content. The $\mathrm{C} / \mathrm{N}$ ratio values in the mounds are slightly broader than in the reference chernozem. Such a broadening of the $\mathrm{C} / \mathrm{N}$ ratio value is related to diagenetic changes, resulting from the burying of soil material under an overlying mound and cutting it off from the impact of an active soil-forming environment [Bednarek 2002].

Barrow building materials are alkaline and show no difference in this regard when compared to the reference profile. High $\mathrm{pH}$ values (7.3-8.8 in $\mathrm{H}_{2} \mathrm{O}$ and 7.2-7.6 in $\mathrm{KCl}$ ) are connected with the ubiquity of calcium carbonate. Its content, however, differs between the barrows. In the mound of Klembivka 1, it stays in principle between 0.2 and about 1.0 per cent. In Prydnistryanske 1-IV, the building material as a rule contains from about 1.0 to 3.5 per cent of $\mathrm{CaCO}_{3}$.

The content of phosphorus, an element that is often treated as an indicator of organic remains accumulation as a result of human activity [Markiewicz 2008], has no diagnostic significance in the case of the studied barrows. In Klembivka 1 mound, Pt content is $300-450 \mathrm{mg} \mathrm{kg}^{-1}$. In Prydnistryanske 1-IV, it is considerably higher: $650-850 \mathrm{mg} \mathrm{kg}^{-1}$, but still stays below the high values found for the geochemical background in the Prydnistryanske 1 reference profile (up to $1100 \mathrm{mg} \mathrm{kg}^{-1}$ ) and the remains of the top parts of fossil soils preserved underneath the barrows. As already mentioned, such an anomaly is probably geogenic in nature.

A comparison of all the above characteristics of the mounds of barrows Klembivka 1 and Prydnistryanske 1-IV with the properties of the chernozem in the reference profile Prydnistryanske 1 permits the conclusion that they were built of the material coming from the humic horizon A, that is, the surface mineral horizon of soil, from a depth not exceeding $0.5 \mathrm{~m}$.

Contemporary ploughing horizons on barrows differ from the principal parts of mounds in a slightly higher carbon and nitrogen content, and slightly lower $\mathrm{pH}$ values and phosphorus content. Immediately below the ploughing horizons, in both barrows, there is a zone of poor $\mathrm{CaCO}_{3}$ accumulation, which can be seen to be a poorly developed analogue of the calcic horizon found in the profile of natural chernozem. The content of $\mathrm{CaCO}_{3}$ grows in this zone up to about 1.3 per cent in Klembivka 1 and 5-7 per cent in Prydnistryanske 1-IV. Both the distinctive character of the ploughing horizon and the accumulation of carbonates immediately underneath it are the effects of the ongoing soil-forming process characteristic of the steppe environment. This process results in the development of a successive generation of chernozems in the roofs of anthropogenic barrow mounds. This fact suggests a conclusion that the direction of pedogenesis is continued and, thus, that the environmental conditions have remained relatively stable in the vicinity of Yampil since the time the barrows were built up to this very day. 
Initial calcic horizons, found in upper parts of barrows extend at various depths. In Klembivka, it is $45 \mathrm{~cm}$ below the contemporary land surface analogously to the Prydnistryanske 1 reference soil profile. In barrow Prydnistryanske 1-IV, the carbonate accumulation zone begins already at the ground level. In the same barrow, slightly better marked, morphologically observable fragments of the calcic horizon (Fig. 3a, b) are found on the barrow mound sides, although they are inclined at a more acute angle than the mound slopes. This arrangement of the carbonate accumulation horizons suggests that barrow Prydnistryanske 1-IV was a subject of denudation and an agro-erosive removal of the top portion of its mound at least approx. $0.5 \mathrm{~m}$ thick and its re-deposition in the lower portions of the slopes.

\section{CONSLUSIONS}

The Yampil Barrow Complex located in south-eastern part of western Ukraine, lies in the steppe zone, where typical chernozems dominate in the soil cover. In this work these soils are represented by the Prydnistryanske 1 soil profile - acc. to WRB 2015: Vermic Hypocalcic Chernozem (Loamic, Pachic).

Anthropogenic sediments building the Prydnistryanske 1-IV and Klembivka 1 barrows were collected from the top humic horizons A of surrounding Chernozems, from maximum $0.5 \mathrm{~m}$ deep layer of soil.

Effects of secondary, post-depositional soil forming processes are seen in the morphology and chemical properties of materials building burial mounds: humus accumulation, initial calcic horizon formation and phosphorus redeposition. As the effect of agro-denudation the burial mound Prydnistryanske 1-IV has been lowered about $0.5 \mathrm{~m}$. 


\section{REFERENCES}

Baliuk S., Medvedev V., Kucher A., Solovey V., Levin A., Kolmaz Y.

2017 Ukrainian chernozems as a factor in global food security and resilience of agriculture to climate change. In: Global Symposium on Soil Organic Carbon, 1-6. Rome.

Bednarek R.

2002 Diagenetic changes in sandy buried soils. In: B. Manikowska, K. Konecka-Betley, R. Bednarek (Eds) Paleopedology problems in Poland, 47-57. Łódź.

2007 Znaczenie studiów paleopedologicznych w archeologii środowiskowej. In: M. Makohonienko, D. Makowiecki, Z. Kurnatowska (Eds) Studia interdyscyplinarne nad środowiskiem i kultura w Polsce. Środowisko-Człowiek-Cywilizacja 1: 71-91. Poznań.

Bednarek R., Jankowski M.

2014 Charakterystyka gleboznawcza materiału budującego nasyp kurhanu 1 w Pidlisivce. In: A. Kośko, M. Potupczyk, S. Razumow (Eds) Naddniestrzańskie kompleksy cmentarzysk kurhanowych społeczności z III $i$ z pierwszej połowy II tysiaclecia przed Chr. w okolicach Jampola, obwód winnicki. Z badań nad północno-zachodnią rubieża osadnictwa społeczności kręgu kultur „wczesnobrazowych” strefy pontyjskiej. Badania z lat 1984-2014. Archaeologia Bimaris - Monografie 6, 275-279. Poznań.

Bednarek R., Prusinkiewicz Z.

1980 Geografia gleb. Warszawa.

Boguckyj A., Dmytruk R., Łanczont M., Madeyska T., Jacyšyn A.

2007 Paleogeograficzne uwarunkowania współczesnych krajobrazów w dolinie środkowego Dniestru. In: U. Myga-Piątek (Ed.) Doliny rzeczne - Przyroda-krajobraz-człowiek. Prace Komisji Krajobrazu Kulturowego PTG 7, 191-201. Sosnowiec.

\section{IUSS Working Group WRB}

2015 World Reference Base for Soil Resources 2014, update 2015. International soil classification system for naming soils and creating legends for soil maps. World Soil Resources Reports No. 106. FAO. Rome.

Jankowski M., Dąbrowski M., Jasińska J., Michalski A.

2017 Yampil Barrow Complex: Prydnistryanske 1 and Klembivka 1. Pedological-environmental aspects of location. Baltic-Pontic Studies 22: 41-53. 
Karpachevski L. O.

1983 Zierkalo landshafta. Moskva.

Klochko V.I., Kośko A., Razumov S.M., Włodarczak P., Żurkiewicz D.

2015a Eneolithic, Babyno and Noua culture cemeteries, Klembivka, site 1, Yampil Region, Vinnitsa Oblast: archaeometry, taxonomy and topogenetics. Baltic-Pontic Studies 20: 142-182.

Klochko V.I., Kośko A., Potupchyk M., Włodarczak P., Żurkiewicz D., Ivanova S.V.

2015b Tripolye (Gordineşti group), Yamnaya and catacomb culture cemeteries Prydnistryanske, site 1, Yampil Region, Vinnitsa Oblast: an archaeometric and chronometric description and a taxonomic and topogenetic discussion. Baltic-Pontic Studies 20: 83-255.

Markiewicz M.

2008 Diagnoza zasięgu oraz intensywności dawnej działalności człowieka na podstawie badań gleb na wybranych stanowiskach archeologicznych ziemi chełmińskiej. Toruń.

Siemiradzki J.

1922 Geologja ziem polskich. 1. Formacje starsze do jurajskiej włącznie. Lwów.

Zastawnyj F., Kusiński W.

2003 Ukraina: przyroda - ludność - gospodarka. Warszawa. 